\title{
THE ELECTORAL SYSTEM AND CONFLICT IN MOZAMBIQUE
}

\author{
By \\ Luís de Brito
}

\author{
Dr Luís de Brito is Associate Professor of Political Anthropology \\ at the Universidade Eduardo Mondlane. \\ Caixa Postal 1558 Maputo Mozambique \\ Tel: $(258-1) 492571$
}

\section{PReLiminary Considerations}

The idea of representative multiparty democracy is a dominant feature of the processes of political transition in many African countries today. This assigns an important role to the electoral system within the political framework of the continent. The electoral system can either enhance or hinder the development of the political system. In the first instance, it contributes to the peaceful and institutionalised resolution of political conflicts, thereby promoting social stability and development. In the second instance, it reinforces contentious factors that can result in forms of violent conflict. In reality, whatever the electoral system, it is always more than a simple, technical and neutral instrument designed to produce the political representation of society. As the product of the history of the struggles of the opposing political forces and the interests of a country, the electoral system - given its practical purposes - plays a director's role in the configuration of both the political arena and its main actors, the parties.

The Mozambican electoral system, as defined by the 1990 Constitution and the 1992 General Peace Accord (GPA), was able successfully to serve the initial transitional process from a one-party society at war to a multiparty democracy. However, the system has exhibited some deficiencies with regard to the consolidation and strengthening of the democratisation process. The political and electoral reality of the country, following two general elections and considering the deep-seated mistrust that still exists between Frelimo and Renamo, shows that it would be advisable to pursue a reform of the electoral system so that it does not become an obstacle to the stability of Mozambique's political system.

The fact that the electoral system is unable to solve political and institutional problems emanating from other social spheres should not lead to the underestimation of its influence. Much as the results of an election depend firstly and fundamentally on the ballot, they also equally depend on the voting system. For instance, during the legislative elections in 1994, had the majority system 
provided for in the 1990 Constitution not been modified, ${ }^{1}$ Renamo would have obtained an absolute majority in the National Assembly (between 140 and 152 of the 250 seats, depending on the definition of the electoral districts). Such a scenario (an elected Frelimo President and an absolute majority for Renamo in Parliament) would certainly have had serious repercussions for the country's stability. Not as spectacular, but no less relevant, is the influence of the electoral system on issues such as the allocation of seats. If, based on the same number of votes, the chosen method for this calculation had been that of the traditional quota and largest remainders (a system that generally favours the small parties) ${ }^{2}$ instead of the highest average d'Hondt method (that favours the large parties), ${ }^{3}$ there would not have been an absolute majority in Parliament, ${ }^{4}$ there would probably have been more transparency and political collaboration. These are only two examples of the influence, decisive at times, the electoral system can exert on the political process.

Notwithstanding the definition of an electoral system that results first and foremost from the dynamics of the political struggles that take place in society, the debate must be extended to a broader analytical framework than that of the main institutional and political actors, enabling, on the one hand, the introduction of social dimensions or interests in the medium and long term and, on the other, the benefit of the knowledge and experience gained by other countries about the functionality of their electoral systems. Mozambique's success in sustaining peace in the last ten years has more to do with the capacity to postpone instability than with the capacity to solve the problems that can revive it, namely those occurring during and immediately after the electoral processes.

\section{Brief Retrospective of Multiparty Elections}

After about three decades of armed conflict, Mozambique has experienced relative peace since 1992. Since then, the country has experienced two general electoral processes (1994 and 1999) and a municipal electoral process (1998). ${ }^{5}$ The background to the current Mozambican electoral system and the main hotspots of conflict in the electoral process form the focal point of the discussion below.

1 During the negotiation of the General Peace Accord in 1992, on Renamo's initiative, the majority system was changed to a proportional representation system.

2 The first step in this method is to calculate a quota, dividing the total number of valid votes in the district by the corresponding number of seats. The parties are then allocated as many seats as the times the quota occurs in their number of votes. Finally, the remaining seats are allocated according to the largest remainders of votes (also included in this phase are those parties that did not attain the quota).

3 In this case, the parties' votes are divided by a series of divisors $(1,2,3,4$, etc...) and the party with the highest result in each stage wins a seat. The procedure continues until all the seats are allocated.

4 See Appendix 1 for simulated calculations of the allocation of seats in the 1994 legislative elections, following different methods.

5 Local elections took place again in November 2003 (after the original presentation of this paper). According to the official results announced by the National Elections Commission, Frelimo obtained an absolute majority in 29 of the 33 municipalities and Renamo gained absolute majorities in the remaining four municipalities. At the time of writing of this note, these results are not yet definitive, they still have to be confirmed by the Constitutional Council. 


\section{Background}

During the 1980s, particularly the second half, the Frelimo government undertook a series of initiatives aimed at establishing peace in the country. After a great deal of indecision and frustrated attempts to convince Renamo to be integrated into Mozambican society without questioning the single party that, meanwhile, had abandoned Marxism-Leninism to present itself as an open front to all Mozambicans, Frelimo adopted a new Constitution, based on a multiparty system, which was subsequently endorsed by the Popular Assembly at the end of 1990 .

The Constitution was approved at a time when the Rome negotiations between the Frelimo government and Renamo were already under way (having commenced in July of the same year) and answered the need to adapt the country's structure and political system. As far as the electoral system is concerned, the Constitution (article 107) provided for a majority system. According to Carrilho's interpretation (1995, pp142-143) this choice would reflect, on the one hand, a coherence with the logic of the system of the presidential government that was in force and, on the other, the concern to 'give the country a parliament that is not fragmented and a cohesive executive'. However, at the Rome negotiations Renamo proposed that the election of MPs to the National Assembly be done through a system of proportional representation. This was eventually accepted and incorporated into the GPA (Protocol III), where it was also defined that the electoral constituencies would correspond to the provinces. In fact, it seems to have been accepted that the proportional system, insofar as it tends to favour a diversified political representation and to avoid the formation of a hegemonic party system, was the one most likely to guarantee Renamo a good political position should it be defeated in an election.

The electoral law 4/93 of 20 December, which was to govern the first multiparty elections, was thus based on the principles established under the GPA. Despite the fact that this law was approved specifically for those first elections, it became the main source of national electoral rights and established the electoral model still in force: the President is elected by absolute majority through direct and universal suffrage in two rounds and in a sole national constituency and MPs are elected through party lists in eleven electoral districts, with at least 5 per cent of valid votes at national level needed as a threshold for the allocation of parliamentary seats.

\section{The 1994 general elections}

The Rome negotiations were drawn out, difficult, and marred by the permanent mistrust between the parties. Even after the signature of the GPA, the construction process of the new democratic order continued to be difficult. The joint commissions to be set out as per the accord were formed tardily and worked under difficult circumstances, and the presidential and legislative elections that were expected to take place the following year (1993) only happened in October 1994. 
The 1994 elections were successful in terms of voter participation, with abstentions slightly above the 12 per cent mark. In the presidential election, the Frelimo candidate, Joaquim Chissano, was elected in the first round with 53.3 per cent of valid votes; the Renamo leader, Afonso Dhlakama, obtained 33.7 per cent. In the legislative elections Frelimo obtained 44.3 per cent and an absolute majority in Parliament with 129 seats; followed by Renamo with 37.8 per cent, corresponding to 112 seats; and the Democratic Union with 5.1 per cent and 9 seats.

The voting process did not escape the mood of mistrust that dominated the process of political transition. Shortly after the process began the Renamo leader announced the withdrawal of his party from the electoral race, a decision based on a series of allegations of fraud perpetrated by Frelimo supporters. Subsequent pressure by the international community persuaded the Renamo leadership to continue to participate in the electoral process and the National Electoral Commission (NEC) extended the electoral period by one more day. Even though the number of complaints regarding the electoral process received by the NEC was relatively low, ${ }^{6}$ Renamo remained adamant that there had been fraud.

The 1994 election revealed a profound polarisation in the Mozambican political arena where the two main political forces found themselves in a situation of relative balance: Frelimo holding 49.6 per cent of the seats and Renamo 44.8 per cent, with the Democratic Union retaining the remaining 5,6 per cent. In addition, and not less importantly, the elections showed that Frelimo and Renamo had different geographical strongholds that translated into areas of clear electoral hegemony for each of them.

Frelimo's victory gave it an absolute majority in Parliament and the opportunity to form a Cabinet without the need for any political alliance. This resulted, in practical terms, in the end of the process of political negotiation and of Renamo's inclusion in the country's political life that had characterised the period following the GPA. In fact, the integration mechanisms that were established by the GPA, namely the joint commissions, were supposed to terminate with the elections, and the agreement did not contain a specific provision to guarantee their continuity in any shape or form. Frelimo rejected the possibility of a government of national unity that had been raised before the elections and opted to govern without any power sharing.

\section{The 1998 local elections}

Frelimo's not-so-inclusive policy with regard to Renamo did not help build mutual trust between the two adversaries. Although Renamo was formally represented in

NEC's final report (1995, pp 77-92) lists a total of 85 complaints or incidents reported and highlights that the irregularities as reported, when confirmed, were not sufficiently serious to invalidate the vote at any of the polling stations. It is worth noting that many complaints could not be investigated as no proof was presented. In addition, the Electoral Tribunal received only three appeals. 
the legislature, with a large number of seats, Frelimo's absolute majority did not allow it any influence over the country's governance. The legislation relating to local authorities that had been approved in 1997 by the National Assembly did not satisfy Renamo, which removed all its members from the NEC and decided not to participate in the municipal elections that were to take place in 33 cities and towns throughout the country in 1998. In addition, Renamo, together with the majority of the small opposition parties, decided to call for an electoral boycott.

The local elections took place on 30 June 1998, with the participation of Frelimo, some small parties and some independent candidates and groups only. The abstention levels were around 85 per cent. To a large extent this can be explained by the absence of effective competition as a result of the opposition's boycott, probably combined with a lack of clarity on the part of the electorate about the role of local authorities.

By boycotting the electoral process, Renamo, which did not have any government position at national level, lost any possibility of gaining any position at local level, thus continuing in a real situation of political marginalisation that in no way corresponded to the electoral weight it had achieved in 1994.

\section{The 1999 general elections}

The second multiparty presidential and legislative elections took place in December 1999. These elections were governed by a new legislative package that had been approved that year but did not introduce any substantial alteration of the law that had governed the 1994 elections. Renamo entered the race as part of an alliance with a good number of the small parties. ${ }^{7}$ As for the presidential election, there were only two candidates: Afonso Dhlakama, for Renamo, and Joaquim Chissano, for Frelimo.

As in the previous electoral processes, the tension between the two adversaries was very high. The official results of the presidential election attributed the victory to Chissano, with 52.3 per cent of the votes, while Dhlakama obtained 47.7 per cent. In the legislative elections, Frelimo obtained 48.6 per cent and Renamo 38.8 per cent, resulting in parliamentary representations of 53 per cent and 47 per cent, respectively. Renamo submitted a series of complaints and eventually an appeal to the Supreme Court, contesting the results and demanding a recount.

Of the two main complaints laid by Renamo, one referred to the non-counting of a large numbers of registers (938 in the presidential and 1170 in the legislative elections) from the 'Zambézia, Sofala and Nampula provinces, where the candidate, Afonso Dhlakama, and the coalition Renamo-Electoral Union obtained the majority of the votes cast' (as per the Determination of the Supreme Court on Renamo-

The coalition was called Renamo-Electoral Union. For practical reasons, and given the party's hegemony within the coalition, we shall continue to use Renamo in this text, even in situations where it refers to the Renamo-Electoral Union. 
Electoral Union's Appeal), which would have equalled about one million voters. The other complaint referred to huge discrepancies between the number of votes cast in the presidential and in the legislative elections, which, given the fact that the voting was running concurrently, was likely to raise doubts about the validity of the results.

In regard to the first complaint, the Supreme Court learnt from the Electoral Administration Technical Secretariat that 550 registers for the presidential elections and 727 for the legislative elections had not been processed because of 'irreparable vices'. These were: 'no indication of the station's code; no indication of the number of votes in the ballot box; no indication of the number of votes per candidate, party or coalition; no indication of the number of valid votes; discrepancies between the number of valid, void and blank votes and the total number of votes in the ballot box; registers and reports with erasures and alterations not confirmed; and registers that had been processed without having been saved into the computers' (Determination of the Supreme Court on Renamo-Electoral Union's Appeal). These omissions would have totalled slightly more than 370000 votes.

As for the second complaint, the Supreme Court accepted the explanation given by the NEC: 'The logical explanation for the mentioned discrepancy in the number of voters is given by the National Electoral Commission in terms that this Court considers acceptable. Although the voting is simultaneous, the counting of the votes is done autonomously; in the legislatives - specifically due to the fact that the number of candidates is substantially larger than in the presidential elections - there were more mistakes made by the polling stations, be it due to the poor filling out of forms, the erasures and alterations not confirmed, or any other such circumstances. One of these mistakes would have been considered to be irreparable. This resulted in a greater reduction of the number of voters in the legislative elections' (Determination of the Supreme Court on Renamo-Electoral Union's Appeal).

Notwithstanding the fact that the 370000 votes not counted were substantially higher than the number of votes that officially separated the two presidential candidates (205 593), the Supreme Court rejected the appeal and validated the results as announced by the NEC. Faced with this decision, Renamo declared that it would not recognise the legitimacy of the institutions and of the government born out of the elections, and began preparing for protest marches. These, however, did not take place because of the floods that had, in the interim, devastated the southern parts of the country, shifting national and international attention from the political process to issues of solidarity and humanitarian aid.

The conflict was to manifest itself tragically a year later, in November 2000, when Renamo organised a series of protests in various parts of the country. Notable among the incidents of violence were the deaths of about a hundred people in Montepuez. Seven police officers and eighteen Renamo supporters died during the confrontations that took place on the day of the protests and, a few days later, at least 75 Renamo supporters died of asphyxiation, in the small cell where they were detained (AIM Reports 5 December 2000). 
This brief description of some of the conflict situations that characterised the Mozambican multiparty elections reveals that although the country had been at peace since 1992, it was a peace that reflected a lack of trust between the major political forces. This was reinforced by the failed negotiation attempts between Renamo and Frelimo in the first half of 2000, which resulted in an internal crisis within Renamo and the expulsion of Raul Domingos, the Renamo parliamentary leader who had headed his party's delegation at the Rome negotiations and was Renamo's most prominent figure after Afonso Dhlakama.

\section{Some Defects in the Current Electoral System}

The task of peacekeeping in any country depends to a great extent on social legitimacy and on the capacity of its political institutions to allow and promote the normal and pacific exercise of political competition and, through the former, the acceptable resolution of conflicts of interest between different social groups. Evidence gleaned from the recent electoral processes suggests that Mozambican policies are still very fragile and there is considerable risk of political eruption. Although these problems (absence of trust and the lack of a policy of inclusion of the opposition in the government system and institutions) cannot be attributed directly to the electoral system in force, it is clear that the system has not facilitated their resolution and, in fact, contributes to exacerbating them.

The first defect in the Mozambican electoral system is that it does not play an active role in promoting political stability in the country. It is generally accepted that the proportional representation system promotes a more accurate representation of social diversity and prevents the emergence of hegemonic party systems that make democratic rotation difficult than do majority party systems that promote party concentration and favour bipartite systems and the formation of absolute majorities in parliament. However, the Mozambican case is one of the exceptions that shows that even with a proportional system one can be faced with a situation that is more typical of a majority system. Indeed, given the political polarisation of Mozambican society, and notwithstanding the fact that the electoral system is proportional, since independence the elections have produced absolute majorities in favour of the ruling party.

The Mozambican political system is typically bipartite, despite the fact that in 1994 the Democratic Union (a coalition of three small parties), as a result of some electoral confusion, managed to obtain slightly more than the 5 per cent of votes at national level and gained some seats, and that Renamo ran as part of a coalition in the 1999 elections. However, even though the small parties allied to Renamo are represented in Parliament, this would not have resulted in a real increase of votes in favour of Renamo. The data from 1994 indicate that most of those parties' votes (about 1 to 2 per cent) could be attributed to errors or to arbitrary voting and not to a true electoral base. The fact that the Democratic Union did not manage to renew its presence in Parliament in 1999 illustrates that these assumptions are correct. 
The absolute parliamentary majority does not encourage government based on negotiation and the political inclusion of the opposition that should be a priority, considering that the country has emerged from a long and destructive civil war. In addition, one still has to consider that, given the electoral balance between the main political forces, one cannot exclude a situation where, as has been mentioned, one of the parties gets an absolute parliamentary majority and the other wins the presidential election. Taking into account that the Mozambican political system is presidential, this type of political cohabitation would seriously jeopardise peace.

Another problem is that the electoral system does not satisfactorily solve the problem of representation of the electorate. In fact, the geographic distribution of the vote results in large areas where each of the big parties is hegemonic (with more than twice the number of votes of the adversary, or more than 70 per cent of the votes, as can be seen on appendices 2, 3 and 4). Frelimo's hegemony is concentrated in the southern provinces and certain areas of Cabo Delgado and Niassa, and Renamo's in large areas of Sofala and Manica provinces, and in some parts of Zambézia province. In these circumstances, the support base of the opposition, at least in the areas where it is hegemonic, will have difficulty understanding why its party is not in government. In this way the legitimacy of the elected government is weakened and the ground is left wide open for the eruption of violence.

A third general problem has to do with the political legitimacy of elected representatives. From the point of view of the quality and legitimacy of the political representation, the fact that the candidates in the legislative elections are chosen on the basis of party lists is another weakness of the system in force, especially because the electoral constituencies are very large, with an important number of voters scattered over an extensive territory (in the 1999 elections, Niassa, the electoral district with the smallest electoral population, had 356693 registered voters and Nampula, the district with the largest, registered 1434764 voters). In the absence of specific mechanisms to solve this problem, the size of the constituencies prevents a real connection, common knowledge and effective communication between MPs and their electorates. This distance reinforces, in turn, one of the worst weaknesses of the list system, which tends to focus on the parties and their leaderships, thus giving less importance to the relationship of the candidates with the voters. These dynamics have repercussions on the way political competition develops, and end up limiting the ground for the expression of rights and the effective participation of citizens in political life. In addition to the general problems mentioned above, the Mozambican electoral experience has highlighted a series of other issues that need to be improved upon. One of the most serious of these is that of the independence of the controlling bodies of the electoral process, in particular the NEC. ${ }^{8}$ Within the environment of political mistrust that prevailed in the country and before agreement could be

8 The leadership, composition and management of the 'STAE' (Technical Secretariat for Electoral Administration) have also been a central point of constant disagreement between Frelimo and the opposition. 
reached on the selection process of the personalities who might guarantee the independent running of such bodies, the solution was to 'politicise' them: each party had the right to choose a number of members proportionate to the number of parliamentary seats held by the party.

The recent attempt to open the selection process of the NEC and the provincial and district chairs to civil society was a fiasco. The NEC law was supported by both parties in the National Assembly. However, the work and discussions of the ad hoc parliamentary commission in charge of producing draft Bills lasted about two years without the two political forces reaching agreement on basic issues. The law (20/2002 of 10 October) was finally unanimously approved after a marathon negotiation of 12 hours that involved the top tiers of the two parties.

One of the crucial points being debated was the selection process of the leaders of the electoral commissions. Renamo had accepted without any qualms that candidates for the NEC's chairmanship be nominated by civil society and elected by members of the Commission. This would be an opportunity to introduce into the controlling bodies of the electoral processes the principle of impartiality and independence from the ruling party.

In line with this, Renamo wanted the election to be based on consensus or a two-thirds majority. ${ }^{9}$ However, Frelimo, which, by virtue of its parliamentary representation, has an absolute majority in the NEC, argued that this could block the process because of lack of consensus and that the chair should be elected by an absolute majority. To a great extent, this killed the spirit underlying the proposal to have a chair nominated by civil society. The imperfections of the law and the nature of 'civil society' resulted in the solution that had been found for the selection of the NEC becoming, almost inevitably, a source of problems and disagreement. Indeed, the nomination process was marred by a huge controversy.

Following the association of some organisations and a process of consultation in all provinces that ended in the selection of three candidates to be presented to the NEC, the Christian Council of Mozambique presented a candidate that Renamo and the majority of the opposition considered to have been 'ordered' by Frelimo. The elections of the NEC's chair showed that there was absolutely no consensus the Frelimo representatives voted for and elected the chair against the opposition block vote, which is a bad omen for the 2004 Presidential and Parliamentary elections.

Despite the fact that the law is very detailed regarding the counting process and the verification of the results, as well as the publication of the registers, this process has been characterised by mistakes and irregularities, and has provoked debate and raised accusations in all elections. On the other hand, experience has shown that the system for the resolution of electoral disagreement, especially with regard to issues relating to verification, has not been satisfactory, leading to suspicion of fraud.

9 The same process would be followed with the commissions at provincial and district levels. 
Electoral census has been a constant problem. Already two have been 'done from scratch' and an updating process is currently under way. Although the published balance sheets of the budgets for the elections did not distinguish what was allocated to the electoral census, it is common knowledge that it constitutes one of the main expenses, thus jeopardising the financial sustainability of the electoral process. Because of the lack of consensus and political decision about the current and permanent updating of the voters' roll this has been another almost constant point of disagreement, forcing the utilisation of resources that could have been better used in other areas of the electoral process.

\section{TOWARDS A REFORM OF THE ElECTORAL SYSTEM}

The difficulties outlined above point to a dire need for a reform of the electoral system so that the most immediate interests of each of the political parties become subordinate to the national interest and to the need to guarantee the best possible conditions for the maintenance of peace and a stable environment conducive to development. The current system has accomplished its mission of enabling a political transition to a multiparty environment, but reveals itself to be less appropriate for the phase of democratic consolidation.

Some general recommendations follow, inspired by the Administration and Cost of Elections Project $(\mathrm{ACE})^{10}$, which could serve as a reference for an eventual revision of the current Mozambican electoral system.

\section{Acceptance by the main actors}

The central concern of each and every electoral system must be to ensure transparency and balance, or, in other words, that the voters understand the results and the losers do not reject them. In this regard there is a clear problem in Mozambique: the first indications that, because of a lack of mutual trust, the system, despite the fact that it had been negotiated by the two major political forces, did not offer sufficient guarantees, go back to the 1994 elections, when Renamo's withdrawal was only prevented by many diplomatic interventions. These indications were reinforced in the 1999 elections by accusations of fraud and Renamo's refusal to accept the Supreme Court's decision on its appeal. Irrespective of the real problem and of who will be proved right, it is evident that there is a problem of trust in the system and in its institutions, specifically in those most directly responsible for its management.

On the other hand, it can easily be presumed that, within an electoral district where the overwhelming majority of the electorate have voted for a party that

10 A joint initiative of the International Institute for Democracy and Electoral Assistance (IDEA), based in Stockholm; of the International Foundation for Election Systems (IFES), based in Washington; and of the United Nations (see www.aceproject.org). 
ends up being defeated at national level, the results of the elections will seem obscure and in conflict with the dominant sentiment, and thus the legitimacy of the result will be questioned. This problem is obviously aggravated by the fact that there is no generalised form of elected local power adapted to the historical and social reality of the country.

\section{Conceptualising a simple system}

This is particularly relevant in a country such as Mozambique for two reasons: firstly, because the majority of the electorate is illiterate and has little access to political information; secondly, because economic ${ }^{11}$, technical and human resources are relatively scarce. From the voting perspective, and in spite of being one of the simplest systems and of the continuous effort to undertake electoral education campaigns to satisfy the needs of a largely illiterate electorate, there still seems to be room to simplify certain procedures relating to the electoral census and administration in general. This would allow for a more cost-effective system.

Special attention should be given to the process of conflict resolution, focusing on issues related to the counting and verification of the results at all levels. One change should be to find a way of forming the electoral commissions to overcome the obstacle of the existing politicisation. This, together with the creation by consensus of an electoral tribunal that will be respected by all parties, could be an effective vehicle for achieving trust and transparency within the electoral processes.

\section{Taking into account the country's political and social context}

The simplification of the system should not be taken as an absolute value to be achieved, whatever the price. In Mozambique, where multiparty democracy is in its early stages, it might even be necessary to make some aspects of the electoral system slightly more complex so as to make it more inclusive by producing a better and particularly more legitimate representation of all the country's citizens. In other words, the simplification efforts should run parallel with the development of mechanisms capable of ensuring a more effective representation of the various interests and groups that make up Mozambican society.

The issue of inclusivity is more prominent in the legislative elections and often arises from the scrutiny, or rather the methods (majority, proportional or mixed) chosen for the calculation and attribution of seats. Ideally, Parliament should represent all interest groups with significant social weight, even when those groups represent a minority. In Mozambique, the problem of representation arises mainly

11 A large portion of the cost of the two national and one municipal electoral processes that have taken place since the creation of the multiparty system was mainly covered by foreign funds. It is imperative that the financial sustainability of the electoral system be one of the main concerns in the efforts towards its improvement and adaptability to the country's current reality. 
from the geographic distribution of the parties' influence and is reinforced by the fact that the Mozambican political system is based on an historical tradition of extremely centralised government. The fact that the voting for each of the two main parties was regionally concentrated, as the 1994 and 1999 results showed, gives rise to a feeling of exclusion on the part of the majority of those who voted for the party that remains in opposition. Generally, the distance between the elected and the electorate they are supposed to represent tends to increase, thereby also increasing the percentage of abstentions (from 13 per cent in 1994 to more than 30 per cent in 1999). This is partly because candidates are elected through party lists from large electoral constituencies, and their re-appointment as candidates is much more dependent on their being in the 'good books' of the party leadership than on work efficiently carried out to try and answer the concerns of the citizens or convey their opinions and expectations.

Experience shows, therefore, that representation and the proximity between voters and MPs are actually the most critical aspects in terms of the legitimacy of the political system. One possible solution to the problem of legitimacy and one which would extend the field of effective participation by the citizens in the framework of an electoral system that is easier for the electoral bodies to manage and simple for the voters would be to introduce a mixed electoral system, which could simplify the vote and, at the same time, combine advantageously the majority system with proportional representation, as is done, for instance, in the German Federal Republic. The extension of municipal power to the whole of the national territory is also a priority.

\section{Promoting open public debate}

The legitimacy of the electoral system depends to a great extent on the process that led to its adoption. The Mozambican electoral system was initially the result of negotiations between the two parties involved in the armed conflict, who then went through a consultative process with the representatives of the small parties. However, the weakness of these small parties made it unfeasible to open the Mozambican political space beyond the horizon of the two large parties. Even though there is almost no representation of the small parties (with votes seldom totalling 2 per cent and the knowledge that great numbers of these votes are incidental) (Brito 2000), it might nevertheless be useful to introduce mechanisms to allow for the participation of independent candidates or small local parties. The 1998 municipal elections did indeed show that small local parties can win sufficient trust to obtain representation, thereby functioning as catalysts in the local political sphere.

The debate about electoral reforms is central to their credibility and legitimacy. This debate should not be monopolised by the representatives of the great political forces but should be open to society and be as wide and inclusive as possible, allowing for the active participation of civil society organisations and interested 
citizens. This is a means to avoid the supremacy over the general interest of immediate interests and the inborn policies of parties in the political arena to consolidate democracy in the long term and to ensure that the opportunity to eliminate an instability risk factor in the country is not lost because of considerations of immediate or short-term party gains.

\section{Maximising the influence of the voters}

Voters need to feel that their vote contributes in some way to the creation of the government and of the policies it will follow. In line with this, the effectiveness of their ability to choose must be broadened: ideally, they should be able to choose not only between parties, but also between candidates from different parties and between different candidates from the same party. Mozambique's proportional representation system, with its closed party lists and large electoral constituencies, is far from contributing to the accountability of those elected to those who elected them. The interests of the voters must be a fundamental concern of the MPs they have elected. A mix of some typical elements of the majority system (for example, the uninominal district with elements of the proportional representation system, as suggested previously), even if it means that the principle of the equal vote might be slightly affected, can give citizens a clearer understanding of the political process and also more and better opportunities to influence political decisions.

\section{Ensuring consistent political parties}

The maximisation of voter influence should not result in extreme fragmentation of political representation, as this would render the system unstable and inefficient. Therefore, favourable conditions should be created for the existence of relatively strong and stable parties capable of playing a role in promoting and guaranteeing democracy. In the case of Mozambique it can be argued that a process aimed at maximising the influence of the voters would not place at risk the position of the big political forces, which have historically achieved an influential position vis-àvis the population. Considering that, in terms of political culture, the one-party model is still dominant in Mozambique, and that internal party democracy is still in its early stages, such a process would simply contribute to greater dynamism and more internal democracy.

The increase in the number of candidates from small parties without any electoral base is a complicating factor in relation to the costs of the electoral process, which could and should be avoided. In this area, three complementary measures could be considered: firstly, all parties should be required to pay a deposit which will only be reimbursed if a minimum percentage of votes is obtained; secondly, the 5 per cent limit should be eliminated, allowing for the selection of the small parties to be based on the 'natural' limit (usually around 2 per cent) that is implied in the counting system for the seats; and finally, the d'Hondt method should be 
replaced by the traditional quota and largest remainders, which is a more accurate representation of the electoral diversity displayed as per the votes cast.

\section{CONCLUSION}

Though it is true that a well-designed electoral system which respects the reality of its country and whose legitimacy is based on consensus between the political forces can play an important role in the nature of political competition and contribute to strengthening democracy, it would be unrealistic to think that the system alone will guarantee such results. Indeed, there are other external factors - the institutions of government, political culture and the structure of the government system - that interfere in the process and determine to a great extent the political life of a country. ${ }^{12}$ These factors need to be discussed and should not be concealed by the issue of the reform of the electoral system.

12 An example is the role of the President of the Republic in the governing system of Mozambique, which is enshrined in the Constitution. If the majority in Parliament is from a different political orientation, the presidential system may be the source of future problems and a serious obstacle in the politics of the country, without it being the fault of the electoral system. 


\section{APPENDIX 1}

Tables showing the potential effects of different electoral systems (Legislative elections of 1994)

Traditional Quota and

D'Hondt Method

Plurality

\section{Largest Remainders}

\begin{tabular}{|c|c|c|c|c|c|c|c|c|c|}
\hline & Frelimo & Renamo & o UD & Frelimo & Renamo & o UD & Frelimc & o Renamc & no UD \\
\hline C.Delgado & 15 & 6 & 1 & 15 & 6 & 12 & 2 & 0 & 0 \\
\hline Gaza & 14 & 1 & 1 & 15 & 0 & 1 & 16 & 0 & 0 \\
\hline Inhambane & 13 & 3 & 2 & 13 & 3 & 2 & 18 & 0 & 0 \\
\hline Manica & 4 & 8 & 1 & 4 & 9 & 0 & 0 & 13 & 0 \\
\hline Maputo C. & 16 & 2 & 0 & 17 & 1 & 0 & 18 & 0 & 0 \\
\hline Maputo P. & 11 & 1 & 1 & 12 & 1 & 0 & 13 & 0 & 0 \\
\hline Nampula & 20 & 31 & 3 & 20 & 32 & 2 & 0 & 54 & 0 \\
\hline Niassa & 6 & 4 & 1 & 7 & 4 & 0 & 11 & 0 & 0 \\
\hline Sofala & 3 & 18 & 0 & 3 & 18 & 0 & 0 & 21 & 0 \\
\hline Tete & 5 & 9 & 1 & 5 & 9 & 1 & 0 & 15 & 0 \\
\hline Zambézia & 17 & 29 & 3 & 18 & 29 & 2 & 0 & 49 & 0 \\
\hline TOTAL & 124 & 112 & 14 & 129 & 112 & 9 & 98 & 152 & 0 \\
\hline $\begin{array}{l}\% \text { of } \\
\text { votes }\end{array}$ & 44.33 & 37.78 & 5.15 & 44.33 & 37.78 & 5.15 & 44.33 & 37.78 & 5.15 \\
\hline $\begin{array}{l}\% \text { of } \\
\text { mandates }\end{array}$ & 49.6 & 44.8 & 5.6 & 51.6 & 44.8 & 3.6 & 39.2 & 60.8 & 0 \\
\hline $\begin{array}{l}\text { Difference } \\
(\%)\end{array}$ & 5.27 & 7.02 & 0.45 & 7.27 & 7.02 & -1.55 & -5.13 & 23.02 & -5.15 \\
\hline $\begin{array}{l}\text { Average } \\
\text { cost of } \\
\text { seat }\end{array}$ & 17062 & 16102 & 17556 & 16401 & $16102 \quad 2$ & 27310 & 21589 & 11865 & 0 \\
\hline
\end{tabular}




\section{APPENDIX 2}

Districts where presidential candidates obtained a number of votes more than double the votes of the opponent (1994)

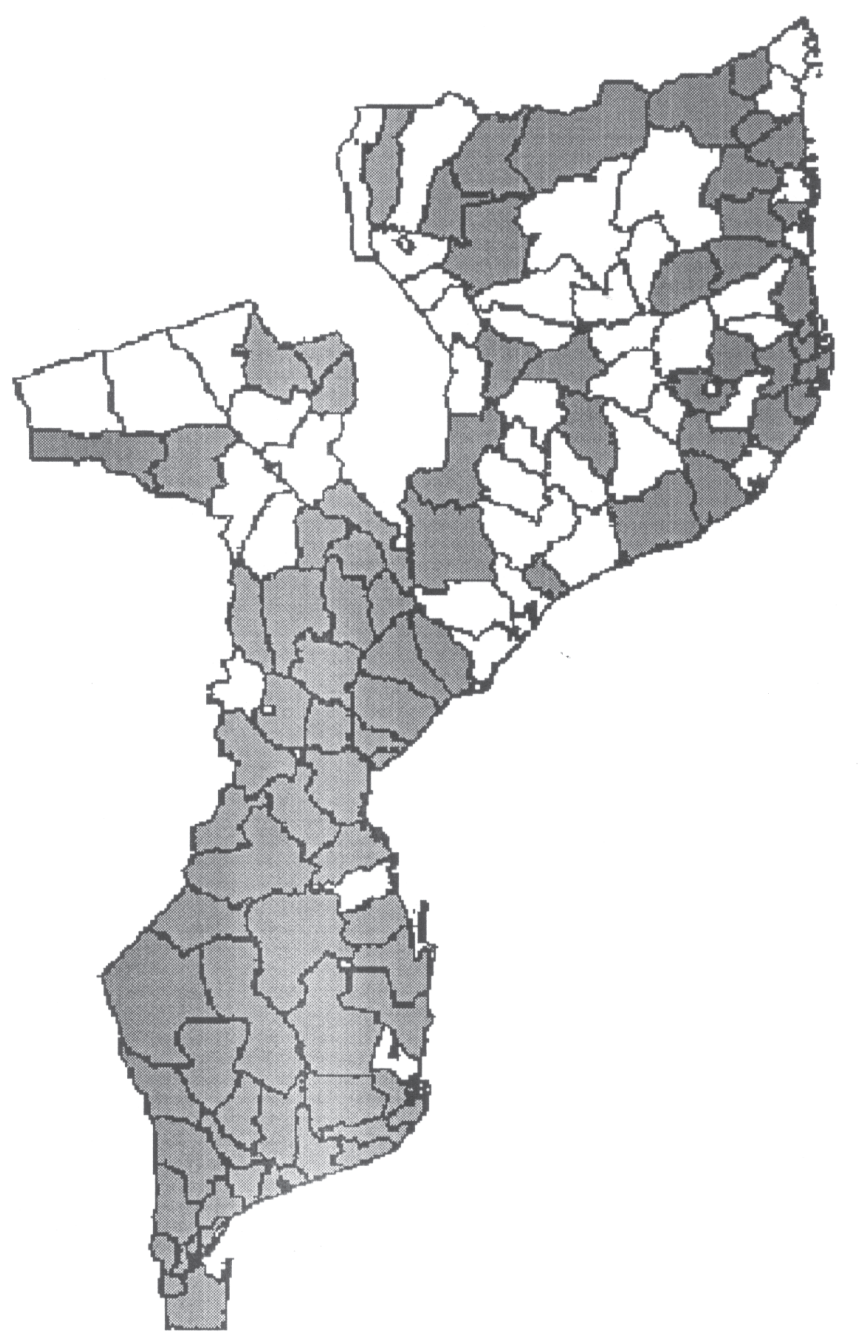




\section{APPENDIX 3}

Districts where Joaquim Chissano obtained more than $70 \%$ of the votes (1999)

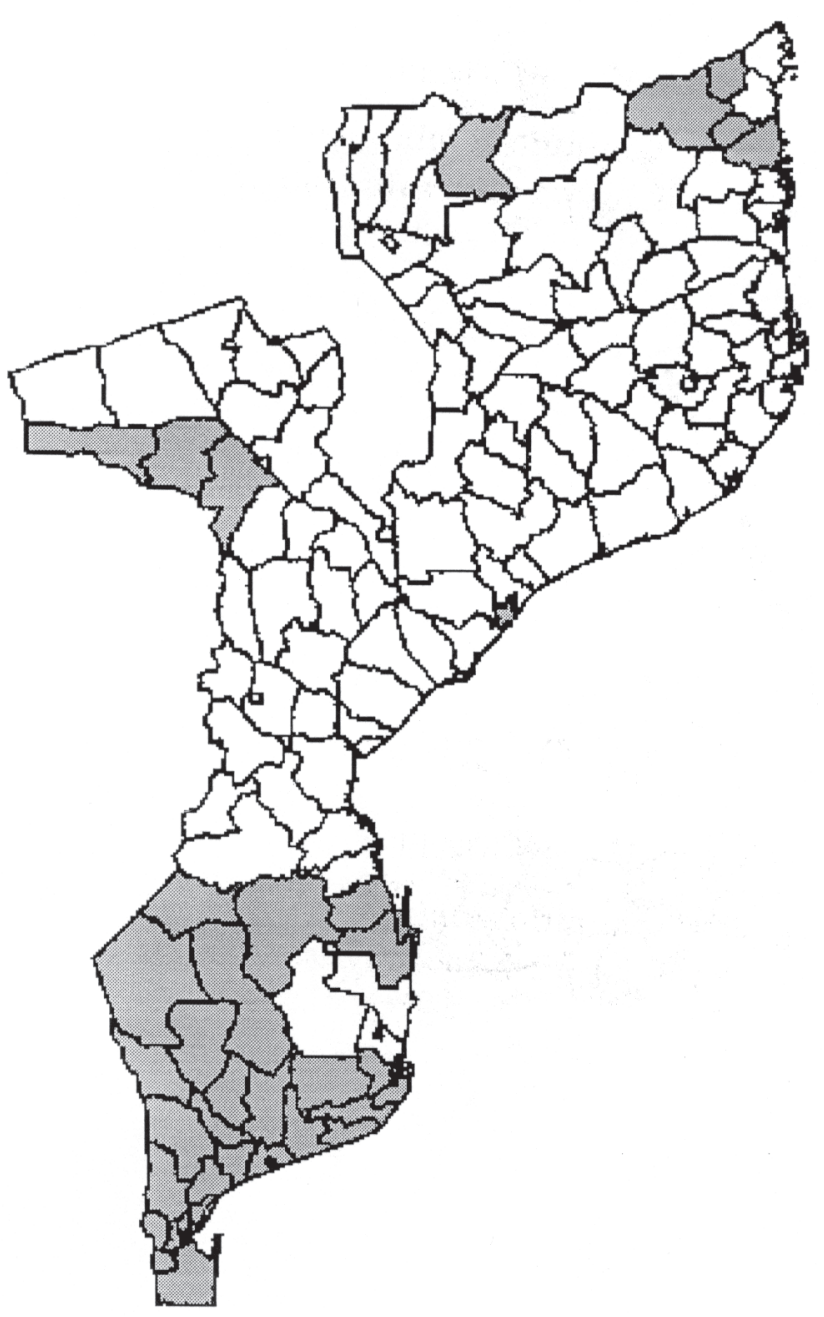




\section{APPENDIX 4}

Districts where Afonso Dhlakama obtained more than $70 \%$ of the votes (1999)

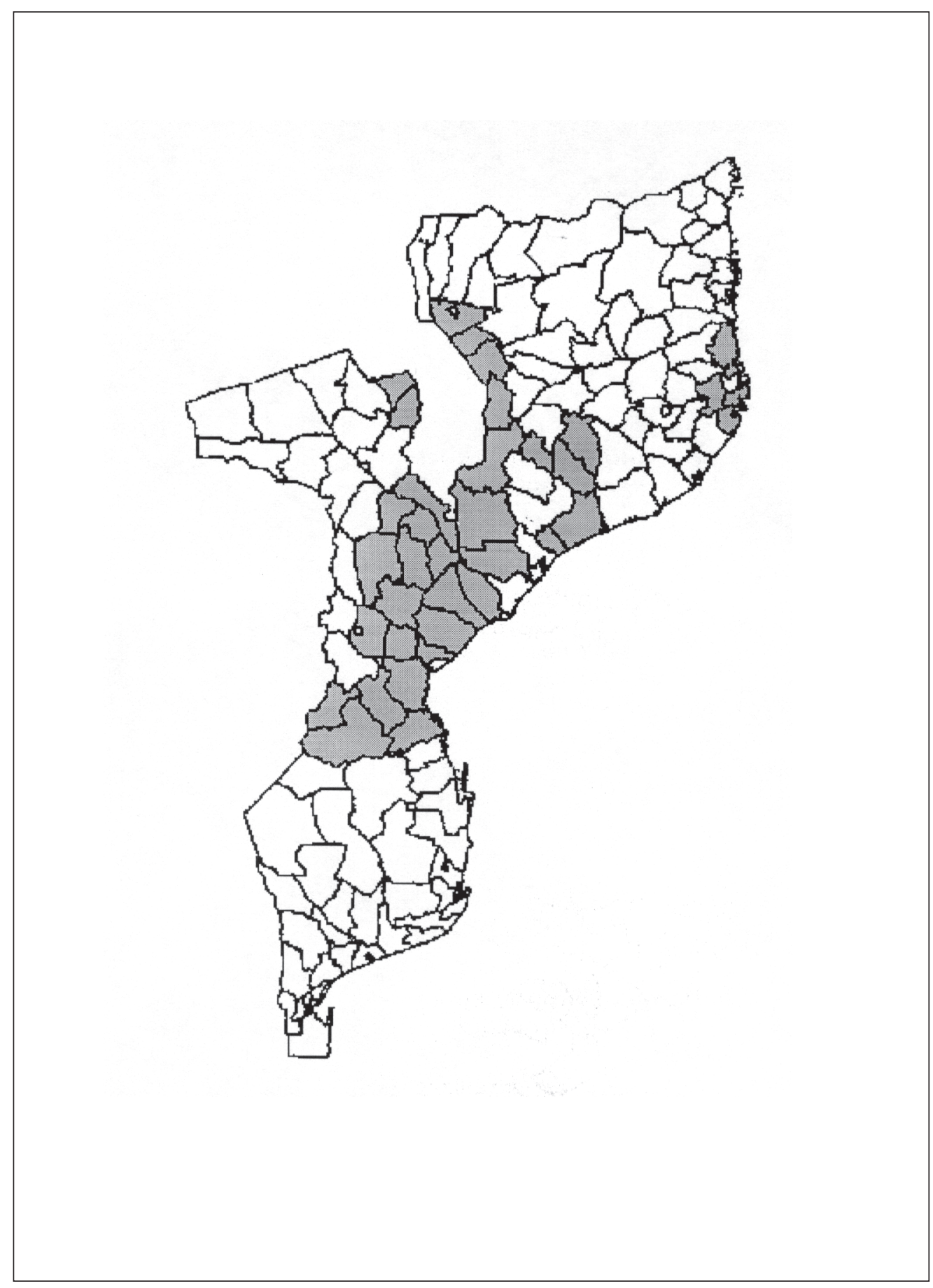




\section{- REFERENCES -}

Acórdão do Tribunal Supremo sobre o Recurso da Renamo-União Eleitoral, 4 de Janeiro de 2000, http:/ / www.mozambique.mz/governo/eleicoes/tsupremo.htm. Acórdão do Tribunal Supremo sobre a Validação e Proclamação dos Resultados Eleitorais, 4 de Janeiro de 2000, http://www.mozambique.mz/governo/eleicoes/ tsupremo.htm.

Acordo Geral de Paz de Moçambique. 1993. Amsterdam: African-European Institute. AIM Reports, $\mathrm{n}^{\circ}$ 196, 5 December 2000.

Baloi, Obede, e José Macuane (eds.). 1998. Conferência Internacional sobre Eleições Autárquicas em Moçambique - Relatório Final. Maputo.

Brito, Luís de. 1995. 'O Comportamento Eleitoral nas Primeiras Eleições Multipartidárias em Moçambique'. In Mazula, Brazão (dir). Moçambique Eleições, Democracia e Desenvolvimento. Maputo.

- 2000. Cartografia Eleitoral de Moçambique -1994. Maputo: Livraria Universitária. Carrasco, António et al. 2001. Eleições Gerais - 1999. Maputo: STAE.

Carrilho, José Norberto. 1995. 'A Legislação Eleitoral em Moçambique e a Realização Política e Social'. In Mazula, Brazão (dir). Moçambique - Eleições, Democracia e Desenvolvimento. Maputo.

Cistac, Gilles. 1994. O Direito Eleitoral Moçambicano. Maputo: Faculdade de Direito da Universidade Eduardo Mondlane.

CNE. 1995. Relatório Final. Maputo.

Dauto, Ussumane Aly. 1999. Legislação Eleitoral. Maputo: edição do autor.

Rocca, Roberto Morozzo della. 1998. Moçambique da Guerra à Paz - História de uma mediação insólita. Maputo: Livraria Universitária. 